\title{
GERBER'S INEQUALITY AND SOME RELATED INEQUALITIES
}

\author{
M. Alić, P. S. Bullen, J. PeČArić AND V. VoleneC
}

Abstract. In this paper simple proofs of various extensions of Bernoulli's inequality and then higher order convexity is used to give more precise forms of these generalizations.

Mathematics subject classification (1991): 26D15.

Key words and phrases: Inequalities, Bernoulli, Taylor's theorem, higher order convexity.

\section{REFERENCES}

[1] M. Alić, J. E. PeČARIĆ AND V. VOLENEC, Note on the Taylor formula and some applications (to appear).

[2] M. Alić, J. E. PeČARIĆ AND V. VoleneC, On the arithmetic mean-geometric mean matrix inequality (to appear).

[3] P. S. BUllen, A criterion for n-convexity, Pacific J. Math. 36 (1971), 81-98.

[4] P. S. Bullen, D. S. Mitrinović And P. M. VAsić, Means and Their Inequalities, Reidel Publishing Co., Dordrecht-Boston, 1988.

[5] LEON GERBER, An extension of Bernoulli's inequality, Amer. Math. Monthly 75 (1968), 875-876.

[6] D. S. Mitrinović (WITH P. M. VAsić), Analytic Inequalities, Springer Verlag, Berlin-Heidelberg-New York, 1970

[7] D. S. Mitrinović And J. E. PeČARIĆ, On Bernoulli's inequality, Facta Univ. (M3), Ser. Math. Inform. 5 (1990), 55-56.

[8] A. W. Roberts and D. E. Varberg, Convex Functions, Academic Press, New York-London, 1973.

[9] H. B. THOMPSON, Taylors theorem with the integral remainder under very weak differentiability assumptions, Aust. Math. Gaz. 12 (1985), 1-6.

[10] H. B. ThOMPSON, Taylor's theorem using the generalized Riemann integral, Amer. Math. Monthly 96 (1989), 346-350. 